\title{
Release of Hydrolytic Enzymes from Cytoplasmic Particles of Solanum Tuber Tissues During Infection by Tuber-rotting Fungi
}

\author{
By D. PITT AND CLARE COOMBES \\ Department of Botany, University of Exeter, Exeter, Devon \\ (Accepted for publication 13 February 1969) \\ SUMMARY
}

\begin{abstract}
Histochemical evidence showed that infection of tuber tissues and tissueculture cells of Solanum tuberosum by Phytophthora erythroseptica, Phytophthora infestans and Fusarium caeruleum caused swelling and disruption of host cytoplasmic particles containing acid phosphatase, esterases and proteases. Heavy diffuse cytoplasmic staining for acid phosphatase was a consistent feature of infection by all three fungi, but staining reactions for esterases and proteases showed much less diffuse staining and a lesser degree of particle swelling. Biochemical assays showed that acid phosphatase was liberated from the particulate fraction to the supernatant fluid fraction of infected callus cells; acid ribonuclease behaved similarly. The biochemical evidence suggested that esterase activity of infected cells remained associated with a sedimentable fraction from cell homogenates. Assay methods for proteolytic enzymes did not confirm the histochemical evidence of a particulate localization of these enzymes in healthy or infected callus tissues. An excess recovery of ribonuclease from tissues infected with $P$. infestans and $F$. caeruleum was found; the significance of this is discussed. Attempts to separate a particulate fraction rich in hydrolases from homogenates of healthy or infected potato tubers were unsuccessful.
\end{abstract}

\section{INTRODUCTION}

The spherosomes of plant cells have affinities with the lysosomes of animal cells (Gahan, 1965; Matile, Balz, Semadeni \& Jost, I965; Walek-Czernecka, I965; Pitt, 1968). Balz (1966) and Semadeni (1967) have provided convincing evidence that the spherosomes represent organelles equivalent to the lysosomes of animal cells. Although lysosomes have been implicated in a number of cellular processes (de Duve, I963) particular attention has been directed to their role in animal cell pathology (Allison \& Mallucci, I965; Mallucci \& Allison, 1965; Bernheimer \& Schwartz, I964; Johnson, 1968). Histochemical observations (Pitt \& Coombes, 1968) have shown that during infection of Solanum tissues by Phytophthora erythroseptica there was swelling and disruption of lysosome-like host-cell particles, accompanied by increased diffuse cytoplasmic staining for acid phosphatase and esterase. The present work adopts a primarily biochemical approach complemented with relevant histochemical observations to discover whether lysosomal damage occurring as a symptom of pink-rot disease of potato tubers, revealed by predominantly histochemical methods in earlier work (Pitt \& Coombes, I968), is a general feature of infection of potato tubers and callus tissues by other tuber-rotting fungi. 


\section{METHODS}

Infecting agents. The isolate of Phytophthora erythroseptica Pethybr. was that used earlier (Pitt \& Coombes, I968). Fusarium caeruleum (Lib) Sacc. was isolated from a tuber of Solanum tuberosum cv. Arran Pilot showing symptoms of dry-rot disease. The culture of Phytophthora infestans (Mont.) de Bary, Race I :4, was kindly supplied by Professor N. F. Robertson (University of Hull).

Solanum. Potato tubers cv. Majestic were grown from the stock used in earlier experiments (Pitt \& Coombes, I968), and callus cultures were obtained and maintained by the methods of Ingram \& Robertson (1965).

Inoculation of callus cultures and tubers. Callus tissues were grown as previously reported (Pitt \& Coombes, I968) and inoculated with a disc of the appropriate fungal culture. Cultures of Phytophthora erythroseptica and Fusarium caeruleum were grown on malt extract agar and those of $P$. infestans on sliced green-bean agar (Ingram \& Robertson, 1965). Potato tubers were wound-inoculated with discs of agar cultures of $P$. erythroseptica or $F$. caeruleum, then wrapped in greaseproof paper and incubated in polythene bags at $20^{\circ}$ for I week and 4 weeks, respectively, before examination. Half tubers were inoculated with sporangial suspensions derived from plate cultures of $P$. infestans and incubated in damp chambers for 3 to 4 days.

Microscopy. Observations were made with a Leitz Ortholux microscope equipped as previously described (Pitt \& Coombes, 1968).

\section{Histochemical methods}

Tissue culture material or tuber tissues were fixed in Baker's formol-calcium or neutral formalin for $\mathrm{I} 6 \mathrm{hr}$ at $0^{\circ}$ to $4^{\circ}$, washed in distilled water and sectioned, where appropriate, on a freezing microtome at $25 \mu$ to $50 \mu$. All observations were repeated with fresh callus tissues and fresh hand-cut tuber sections. Tests for proteolytic enzymes were done on unfixed material only.

Acid phosphatase. The standard coupling azo dye method of Grogg \& Pearse (1952) was normally used, with results checked by other methods (Pitt \& Coombes, I968).

Esterases. Methods included those used in earlier work (Pitt \& Coombes, 1968), with $\alpha$-naphthyl acetate coupled with Fast blue B salt (G. T. Gurr, Ltd.) as the routine procedure.

Proteolytic enzymes. Leucine aminopeptidase activity was located in fresh hand-cut sections of healthy and infected potato tuber tissues and in unfixed tissue culture cells by the method of Nachlas, Crawford \& Seligman (1957) with L-leucyl- $\beta$-naphthylamide (Koch-Light Laboratories Ltd.) as a substrate and incubation times of 60 to $90 \mathrm{~min}$. at $37^{\circ}$. This method was also used with some of the artificial substrates proposed by Nesvadba (1962), which included tyrosine- $\beta$-naphthylamide (Koch-Light. Ltd.) and glycyl- $\beta$-naphthylamide hydrochloride (Koch-Light, Ltd.).

\section{Biochemical methods}

Attempts were made to prepare a lysosomal fraction from fresh potato tuber tissue by grinding tissues cooled to $0^{\circ}$ in a mortar with washed sand and ice-cold $0.25 \mathrm{M}$ sucrose. The homogenate was filtered through cheese cloth, centrifuged for ro $\mathrm{min}$, at $2000 \mathrm{~g}$ at $0^{\circ}$, the sediment discarded and the supernatant fluid further centrifuged for $20 \mathrm{~min}$. at $35,000 \mathrm{~g}$ at $0^{\circ}$. Enzyme assays showed high acid phosphatase, esterase 
and ribonuclease (RNase) activities in the supernatant fluid fractions from healthy or diseased tubers, but negligible activity in the particulate fractions. Because of the frequent difficulties encountered in the preparation of active sub-cellular particulate fractions from storage tissues many modifications were made to the extraction medium; these included the addition of tris buffer $\left(\mathrm{pH}_{7} \cdot \mathrm{I}\right)$, I mM-EDTA, $0.00 \mathrm{I} \mathrm{M-}$ cysteine hydrochloride and $0.00 \mathrm{I} \mathrm{M}$-ascorbic acid, but all lysosomal fractions were low in hydrolase activity. No protease activity was found in either the supernatant fluid or particulate fractions with natural or artificial substrates with an extraction medium of $0.25 \mathrm{M}$-sucrose with or without tris buffer $(\mathrm{pH} 7 \cdot \mathrm{I})$. Since all efforts to isolate an active lysosomal fraction from potato tubers by using a range of sucrose concentrations up to $0.5 \mathrm{M}$ failed, the biochemical methods were applied to homogenates of healthy and infected callus tissues from which lysosomal fractions rich in hydrolase activity were readily prepared. Healthy and infected callus tissues were homogenized, after appropriate incubation periods, by the technique of Pitt \& Coombes (1968) whereby minimum disruption of the fungal component occurred. The progress of infections was followed microscopically and infected and control calluses were harvested and homogenized separately for $4 \mathrm{~min}$. in $0.25 \mathrm{M}$-sucrose by using a Pyrex glass homogenizer rotating at approximately $200 \mathrm{rev} . / \mathrm{min}$. at $0^{\circ}$ to $4^{\circ}$. Experiments with tissues infected with Phytophthora erythroseptica and P. infestans showed that centrifugation of the homogenate for $10 \mathrm{~min}$. at $2000 \mathrm{~g}$ at $0^{\circ}$ deposited most of the unbroken cells, nuclei, cell debris and partially broken fungal mycelium. The deposit was discarded and the supernatant fluid was further centrifuged for $20 \mathrm{~min}$. at $35,000 \mathrm{~g}$ at $0^{\circ}$ to give a clear supernatant fluid and a pellet consisting of a homogeneous particulate fraction rich in mitochondria and lysosomes. It was necessary with homogenates derived from calluses infected with Fusarium caeruleum to give a first centrifugation for Io min. at $3000 \mathrm{~g}$ to sediment out the smaller mycelial fragments arising from this septate mycelium. Attempts to improve the stability of the lysosomal component of tissues by homogenizing in $0.25 \mathrm{M}$-sucrose containing I mM-EDTA and buffered at $\mathrm{pH} 7 \cdot \mathrm{I}$ with $\mathrm{O} \cdot \mathrm{I} \mathrm{M}$-tris buffer were unsuccessful. Consequently all cell fractionations of tissue culture material were made in $0.25 \mathrm{M}$-sucrose. The pellet from the second centrifugation was resuspended and made up to volume with $0.25 \mathrm{M}$-sucrose at $0^{\circ}$ and enzyme determinations done on the supernatant fluid and lysosomal fractions as follows.

Acid phosphatase. The method of Berthet \& de Duve (I95I) was used as described by Pitt \& Coombes (1968), with $\beta$-glycerophosphate as the substrate and an incubation time of $20 \mathrm{~min}$.

Esterase. The method was that of Nachlas \& Seligman (1949), in which enzyme preparations were incubated with $\alpha$-naphthyl acetate in $0.05 \mathrm{M}$-veronal buffer $\left(\mathrm{pH} \mathrm{7.4)}\right.$ for $20 \mathrm{~min}$. at $20^{\circ}$. An ice-cold solution of Fast blue B salt was added with shaking followed by the addition of trichloroacetic acid to $\mathrm{I} \%(\mathrm{w} / \mathrm{v})$. The coloured complex was then extracted with ethyl acetate, the organic layer separated after centrifugation at $1000 \mathrm{~g}$ for $5 \mathrm{~min}$., and extinction readings made at $520 \mathrm{~nm}$. A standard curve was obtained by using known concentrations of $\alpha$-naphthol coupled with Fast blue B salt and subjected to the above procedure.

Acid ribonuclease: $0.5 \mathrm{ml}$. of $0 . \mathrm{I}$ M-acetate buffer $(\mathrm{pH} 5.0)+0.05 \mathrm{ml}$. of I \% (w/v) yeast RNA (highly polymerized; British Drug Houses) + I ml. of enzyme preparation were incubated for I hr at $37^{\circ}$. The reaction was stopped by adding $\mathrm{I} \cdot 5 \mathrm{ml}$. of $0.25 \%$ 
(w/v) uranyl acetate in $4 \%(w / v)$ perchloric acid. The precipitated RNA was removed by centrifugation for $10 \mathrm{~min}$. at $1000 \mathrm{~g}$ and the supernatant fluid was diluted $\mathrm{I} / 4$ with distilled water. The differences in extinctions at $260 \mathrm{~nm}$ between incubated and non-incubated samples were corrected for non-enzymic degradation of RNA.

Acid deoxyribonuclease (DNase). The method for RNase was used but with $0.5 \%$ (w/v) calf thymus DNA (highly polymerized, British Drug Houses) replacing RNA as substrate.

Protease. All attempts to assay aminopeptidase activity by the hydrolysis of artificial substrates, including $\beta$-leucyl, $\beta$-glycyl or $\beta$-tyrosylnaphthylamide as proposed by Nesvadba (1962), were unsuccessful over a wide range of $\mathrm{pH}$ values and in the presence of several known activators of these enzymes. Similarly no protease activity was found in cell fractions by using natural substrates (denatured haemoglobin, casein, egg albumin). The phenol colour method and the procedures found successful by Matile (1964) and Matile et al. (1965), who worked with Neurospora and lysosomal fractions from corn and tobacco seedlings, respectively, were used.

Protein determinations. Soluble proteins in enzyme preparations were determined colorimetrically with the Folin phenol reagent by the method of Lowry, Rosebrough, Farr \& Randall (I95I).

\section{RESULTS}

Total hydrolase activities of Solanum callus cells were determined after homogenisation in $0.25 \mathrm{M}$-sucrose containing I \% Triton X-IOO or after freezing and thawing the calluses several times before homogenization. By using such determinations for comparison it was found that about $30 \%$ of acid phosphatase, $40 \%$ of esterase and $70 \%$ of RNase activities were sedimentable by the fractionation procedure adopted. Experiments showed that the enzyme activity of cell fractions from calluses of different ages varied appreciably; but several assays on calluses of similar size and age and on the same callus showed agreement within $\pm 10 \%$. To minimize such variation, calluses of the same age and size were used for acid phosphatase and esterase determinations, since at least 2 to $3 \mathrm{~g}$. fresh weight of tissue were required for each determination and it was not possible to obtain regularly calluses of 5 to $6 \mathrm{~g}$. fresh weight to permit sampling of healthy and infected tissue from the same callus. Furthermore, the rate of spread of a fungal pathogen through a callus varies and permits only an arbitrary assessment of the extent of infection. However, since each RNase assay required about $\mathrm{I} g$. fresh weight of callus tissue it was possible to obtain at least three samples from each callus during the course of infection, thus eliminating some variation between calluses.

\section{Staining reactions of infected and uninfected tissues of Solanum}

Fixed callus cells and tuber sections of healthy and infected potato tissues were stained for acid phosphatase and esterase. All observations were repeated with unfixed tissues. Since the method for aminopeptidase is only applicable to living material observations were confined to fresh tissues.

Acid phosphatase. Uninfected tuber tissues and tissue culture cells, either fixed or unfixed, contained numerous particles which stained brown by the standard coupling azo dye method with incubation for $15 \mathrm{~min}$. at $37^{\circ}$. Staining of fresh and fixed callus tissues and tuber sections revealed that infection by Phytophthora erythroseptica, 
$P$. infestans and Fusarium caeruleum resulted in swelling and disruption of host cell lysosomes, accompanied by greatly increased cytoplasmic staining. The time sequence of swelling and disruption of these particles varied with the pathogens used. Thus, callus cells infected with $P$. erythroseptica showed maximum particle swelling and diffuse cytoplasmic staining 3 to 4 days after infection. Infection with $P$. infestans and $F$. caeruleum produced comparable reactions at 5 and 7 days after inoculation, respectively. The spread of the pathogens within tubers was also variable with P. erythroseptica and $P$. infestans, having comparable effects on host cell lysosomes I week after inoculation, whereas similar effects were generally detectable 4 to 6 weeks after tuber infection with $F$. caeruleum.

Esterase. The responses to esterase staining of living and fixed callus cells and tuber sections showed that uninfected tissues contained small discrete particles which stained black when using a substrate of $\alpha$-naphthyl acetate accompanied by negligible cytoplasmic staining. Esterase staining of tissue culture cells and tuber tissues infected with Fusarium caeruleum and Phytophthora infestans gave results substantially similar to those reported by Pitt \& Coombes (I968) following infection of potato tuber tissues and callus cells with $P$. erythroseptica. Such staining of fixed and fresh tissues showed swelling of host-cell lysosomes to two or three times their size in healthy tissues, accompanied by a small but definite increase in diffuse cytoplasmic staining. The time sequence of swelling and disruption of infected tissues closely followed that found for the various pathogens by using the acid phosphatase staining procedure.

Aminopeptidase. The response of fresh callus cells and tuber sections to staining for aminopeptidases indicated that such activity in healthy tissues was largely confined to cytoplasmic particles similar in size, shape and distribution to the lysosome-like particles containing acid phosphatase, esterases and $\beta$-D-galactosidase reported by Pitt $\&$ Coombes (1968). Infection of callus tissue and potato tubers by all three pathogens resulted in responses similar to those observed by staining for esterase and acid phosphatase.

\section{Enzyme assays of cell fractions of infected and healthy tissue culture cells of Solanum}

The histochemical results indicated that all three pathogens caused disruption of the lysosome-like particles within the host cytoplasm. Confirmation that such disruption resulted in the liberation of considerable amounts of the hydrolases was obtained by enzyme assays for acid phosphatase and acid RNase of the supernatant fluid (S) and the particulate (P) fraction of healthy and infected callus tissue cell homogenates. Table I shows that acid phosphatase activity of the particulate fractions of callus tissues infected by all three pathogens was appreciably less than for the appropriate control. Infection by Phytophthora infestans and Fusarium caeruleum resulted in large increases in soluble enzyme activity. Such an increase was less pronounced following infection by $P$. erythroseptica.

The results in Table 2 conflict with the histochemical findings in showing increases in the esterase activities of particulate fractions derived from infected cells. These results are discussed later.

Although there is no suitable method for locating RNase activity, there is abundant biochemical evidence that this enzyme, along with DNase, is associated with animal cell lysosomes, and Matile et al. (1965) showed biochemically that RNase is associated with the particulate fraction from corn and tobacco seedlings. Table 3 shows that 
RNase activity of callus cells was associated with the particulate fraction and was liberated to the supernatant fluid in infected tissues. The high RNase activities of the cell fractions permitted the use of small quantities of tissue for each assay, thus allowing three enzyme determinations to be made for each host/parasite combination on

Table I. Solanum callus tissue infected with Phytophthora erythroseptica, $P$. infestans or Fusarium caeruleum

Acid phosphatase activity in particulate $(\mathrm{P})$ and supernatant fluid $(\mathrm{S})$ fractions of potato callus tissue.

\begin{tabular}{|c|c|c|c|c|}
\hline \multirow[b]{2}{*}{ Treatment } & \multicolumn{2}{|c|}{$\begin{array}{l}\text { Activity of fractions. } \\
\text { Inorganic phosphate released } \\
\left(\mu \mathrm{g} . \mathrm{P}_{i} / 20 \mathrm{~min} . / \mathrm{mg} \text {. protein }\right)\end{array}$} & \multicolumn{2}{|c|}{$\begin{array}{c}\text { Total activity } \\
(\mathrm{P}+\mathrm{S} \text { fractions) in fractions } \\
(\%)\end{array}$} \\
\hline & $\mathbf{P}$ & $\mathbf{S}$ & $\mathbf{P}$ & $\mathbf{S}$ \\
\hline $\begin{array}{l}\text { P. erythroseptica } \\
\text { Uninfected } \\
\text { 4-Day infected }\end{array}$ & $\begin{array}{l}3 \cdot 073 \\
1 \cdot 040\end{array}$ & $\begin{array}{l}2 \cdot 300 \\
2 \cdot 314\end{array}$ & $\begin{array}{l}57 \cdot 19 \\
31 \cdot 01\end{array}$ & $\begin{array}{l}42 \cdot 8 \mathrm{I} \\
68 \cdot 99\end{array}$ \\
\hline $\begin{array}{l}\text { P. infestans } \\
\text { Uninfected } \\
5^{1 / 2} / 2 \text {-Day infected }\end{array}$ & $\begin{array}{l}5.259 \\
2.600\end{array}$ & $\begin{array}{l}3.900 \\
8.971\end{array}$ & $\begin{array}{l}57 \cdot 42 \\
22 \cdot 48\end{array}$ & $\begin{array}{l}42 \cdot 58 \\
77 \cdot 52\end{array}$ \\
\hline $\begin{array}{l}\text { F. caeruleum } \\
\text { Uninfected } \\
4^{1} /{ }_{2} \text {-Day infected }\end{array}$ & $\begin{array}{l}3.055 \\
1 \cdot 985\end{array}$ & $\begin{array}{l}1.430 \\
4.875\end{array}$ & $\begin{array}{l}68 \cdot 11 \\
28 \cdot 94\end{array}$ & $\begin{array}{l}31 \cdot 89 \\
71 \cdot 06\end{array}$ \\
\hline
\end{tabular}

Table 2. Solanum callus tissue infected with Phytophthora erythroseptica, $P$. infestans or Fusarium caeruleum

Esterase activity in particulate $(\mathrm{P})$ and supernatant fluid (S) fractions of potato callus tissue.

\begin{tabular}{|c|c|c|c|c|}
\hline \multirow[b]{2}{*}{ Treatment } & \multicolumn{2}{|c|}{$\begin{array}{c}\text { Activity of fractions. } \\
\alpha \text {-naphthol liberated } \\
\text { (mg. } \alpha \text {-naphthol } / 20 \text { min./mg. protein) }\end{array}$} & \multicolumn{2}{|c|}{$\begin{array}{c}\text { Total activity } \\
(\mathrm{P}+\mathrm{S} \text { fractions) in fractions } \\
(\%)\end{array}$} \\
\hline & $\mathbf{P}$ & $\mathrm{S}$ & $\mathbf{P}$ & S \\
\hline $\begin{array}{l}\text { P. erythroseptica } \\
\text { Uninfected } \\
\text { 3-Day infected }\end{array}$ & $\begin{array}{l}0.115 \\
0.380\end{array}$ & $\begin{array}{l}0.328 \\
0.256\end{array}$ & $\begin{array}{l}26 \cdot 04 \\
59 \cdot 77\end{array}$ & $\begin{array}{l}73 \cdot 96 \\
40 \cdot 23\end{array}$ \\
\hline $\begin{array}{l}\text { P. infestans } \\
\text { Uninfected } \\
\text { 5-Day infected }\end{array}$ & $\begin{array}{l}0.121 \\
0.250\end{array}$ & $\begin{array}{l}0.392 \\
0.583\end{array}$ & $\begin{array}{l}23 \cdot 63 \\
30.00\end{array}$ & $\begin{array}{l}76 \cdot 37 \\
70 \cdot 00\end{array}$ \\
\hline $\begin{array}{l}\text { F. caeruleum } \\
\text { Uninfected } \\
4^{1 / 2} \text {-Day infected }\end{array}$ & $\begin{array}{l}0.126 \\
0.234\end{array}$ & $\begin{array}{l}0.386 \\
0.347\end{array}$ & $\begin{array}{l}24 \cdot 57 \\
40 \cdot 29\end{array}$ & $\begin{array}{l}75 \cdot 43 \\
59 \cdot 71\end{array}$ \\
\hline
\end{tabular}

tissues derived from the same callus. The third observation in each series shows a decline in the activities of the supernatant fluid fractions at late stages of infection. The results in Tables I, 2 and 3 are typical of many similar experiments. The methods used did not show a particulate localization of DNase activity, although some activity was found in the supernatant fluid fractions of healthy and infected cells. No protease activity was found in the particulate or supernatant fluid fractions of healthy or infected callus cells. 
Table 3. Solanum callus tissue infected with Phytophthora erythroseptica, $P$. infestans or Fusarium caeruleum

RNase activity in particulate (P) and supernatant fluid (S) fractions of potato callus tissue

\begin{tabular}{|c|c|c|}
\hline \multirow{2}{*}{ Treatment } & \multicolumn{2}{|c|}{$\begin{array}{l}\text { Enzymo activity of fractions. } \\
\text { Change in extinction } / \mathrm{hr} / \mathrm{mg} \text {. pro }\end{array}$} \\
\hline & $\mathbf{P}$ & $\mathbf{S}$ \\
\hline \multicolumn{3}{|l|}{ P. erythroseptica } \\
\hline Uninfected & $1 \cdot 376$ & 0.890 \\
\hline 5-Day infected & $I \cdot 30 I$ & $I \cdot 244$ \\
\hline 7-Day infected & 0.301 & 0.373 \\
\hline \multicolumn{3}{|l|}{$P$. infestans } \\
\hline Uninfected & $I \cdot 630$ & 0.901 \\
\hline 4-Day infected & $I \cdot 484$ & $3 \cdot 20$ \\
\hline 6-Day infected & $I \cdot 230$ & $1 \cdot 310$ \\
\hline \multicolumn{3}{|l|}{ F. caeruleum } \\
\hline Uninfected & $\mathbf{I} \cdot 298$ & 0.838 \\
\hline 6-Day infected & I. IIO & $5 \cdot 146$ \\
\hline 7-Day infected & I.OIO & $4 \cdot 206$ \\
\hline
\end{tabular}

DISCUSSION

It is well established (Gahan, 1965, 1967; Matile et al. I965; Walek-Czernecka, 1965) that higher plant cells contain organelles having affinities with the lysosomes of animal cells. Balz (1966) and Semadeni (1967) considered that the spherosomes of plant cells are equivalent to animal cell lysosomes. The present histochemical observations confirm the view of Pitt \& Coombes (I968) that infection of potato tuber tissues by Phytophthora erythroseptica results in the liberation of lysosomal enzymes (and extends this concept to other lysosomal enzymes) during infection of potato tissues by other tuber-rotting fungi. Substantial biochemical evidence now supports these observations and shows a decrease in acid phosphatase and RNase activities in the particulate fractions of infected cell homogenates accompanied by increases in the activities of these enzymes in the supernatant fluid fractions. However, infections of callus cells by $P$. infestans and Fusarium caeruleum resulted in a massive increase in RNase activity within the supernatant fluid fractions amounting to an excess recovery of the enzyme as determined from assays of total enzyme activity in healthy callus cells. Such excess recovery of lysosomal hydrolases following homogenization of plant tissues was reported by Matile et al. (1965), but in the present work there is a possibility that some of this activity in the soluble phase may have arisen from fungal secretions. Furthermore, it is likely that at least a part of the enzyme activity of the particulate fraction may have arisen through release during homogenization of some fungal lysosomes, which are known to contain enzymes similar to those of higher plant lysosomes (Pitt, 1968). But, since the RNase determinations for each host/parasite combination were done on the same callus/ and since' a gradual decrease in enzyme activity of the particulate fractions still occurred with progressive infections, it is clear that there was a net loss of such activity from the particulate fractions. This inicated that any fungal contribution to the activity of the latter was smaller than the amount released from the host lysosomes.

The esterase activity of the particulate fractions of infected cells was greater than 
that of the healthy controls, suggesting the possibility that this enzyme was not released during infection. This was not supported by the histochemical evidence, although there is always the possibility that some of the remaining esterase activity of infected cells may have been within particles which were not resolved by the microscopic methods used. However, the behaviour of lysosomal esterase during cell fractionation (Matile et al. 1965) and during lysosomal staining (Holt, 1963) is a matter of conjecture. It has been suggested that lysosomal esterase may not be liberated during lysosomal damage since it is a structural component of the lysosome, or alternatively that it is readily released and becomes attached to other cell particles of different densities which would affect its sedimentability. Furthermore, hydrolysis of the $\alpha$-naphthyl acetate substrate by lipase, which is not believed to be a lysosomal enzyme, could explain the soluble esterase activity in healthy tissues, since according to Matile et al. (I965) esterase does not occur in a free form, at least in corn and tobacco. Thus there is no satisfactory explanation for the distribution of esterase activity in infected Solanum tuber cells at the present time. Elucidation awaits the use of differential substrates and gradient-density techniques.

The failure to detect proteolytic activity using a wide range of conditions and substrates is surprising in the light of the excellent histochemical localization obtained in callus tissues and tuber sections, and the biochemical evidence for a particulate distribution shown by Matile et al. (1965), although it is possible (Matile et al. 1965) that inhibitors of acid protease and possibly other hydrolases gain access to such enzymes during the cell fractionation procedure.

Thus the histochemical evidence from infected Solanum tubers and the biochemical and histochemical evidence from callus tissues strongly indicate that infection by a number of tuber-rotting fungi results in the release of lysosomal enzymes from host plant lysosomes. Whether such infections involve de novo synthesis of such enzymes by the host or the pathogen or merely a redistribution of preformed enzymes is difficult to determine in the presence of an indeterminate and continuously increasing fungal component which cannot be separated from the infected host tissues. The present studies, as with many of the observations on animal tissues (Mallucci \& Allison, 1965; Ballard \& Holt, 1968), do not indicate whether disruption of such particles is a primary cause of cell death. However, Weissman, Kaiser \& Bernheimer (1963) showed that streptococcal haemolytic toxins caused release of lysosomal enzymes from granular fractions of rabbit tissues, and that this preceded liberation of malic dehydrogenase from the mitochondria within such preparations. Similar observations made on intact Solanum cells would be necessary to confirm a primary role of lysosomal damage in tissue infection and cell damage.

\section{REFERENCES}

Allison, A. C. \& Mallucci, L. (1965). Histochemical studies of lysosomes and lysosomal enzymes in virus-infected cell cultures. J. exp. Med. 121, 463 .

Ballard, K. S. \& Holt, S. J. (I968). Cytological and cytochemical studies on cell death and degeneration in the foetal rat foot: The role of macrophages and hydrolytic enzymes. J. Cell Sci. $3,245$.

BALz, H.P. (1966). Intrazelluläre Lokalisation und Funktion von hydrolytischen Enzymon bei Tabak. Planta 70, 207.

Bernheimer, A. W. \& Schwartz, L. L. (1964). Lysosomal disruption by bacterial toxins. J. Bact. $87,1100$. 
BertheT, J. \& DE DuvE, C. (195I). Tissue fractionation studies. I. The existence of a mitochondriallinked enzymatically inactive form of acid phosphatase in rat-liver tissue. Biochem. J. 50, 174 .

DE DuvE, C. (1963). Lysosomes and cell injury. In Injury, Inflammation and Immunity. Ed. by L. Thomas, J. L. Urh and L. Grant. Baltimore: Williams and Wilkins Co.

GAHAN, P. B. (1965). Histochemical evidence for the presence of lysosome-like particles in root meristem cells of Vicia faba. J. exp. Bot. 6, 350.

GaHan, P. B. (1967). Histochemistry of lysosomes. Int. Rev. Cytol. 2I, I.

Grogg, E. \& Pearse, A. G. E. (1952). A critical study of the techniques for acid phosphatase with a description of an azo dye method. J. Path. Bact. 64, 627.

HoLT, S. J. (1963). Some observations on the occurrence and nature of esterases in lysosomes. In The Lysosomes. Ed. by A. V. S. de Reuck and M. P. Cameron, p. I14. London: J. and A. Churchill Ltd.

Ingram, D. S. \& Robertson, N. F. (1965). Interaction between Phytophthora infestans and tissue cultures of Solanum tuberosum. J. gen. Microbiol. 40, 43I.

JoHNSON, B. E. (1968). Ultraviolet radiation and lysosomes in skin. Nature, Lond. 219, 1258.

Lowry, O. H., Rosebrough, N. J., FarR, A. L. \& Randall, R. J. (I95I). Protein measurement with the Folin phenol reagent. J. biol. Chem. 193, 265.

MalluCCI, L. \& Alluson, A. C. (1965). Lysosomal enzymes in cells infected with cytopathic and noncytopathic viruses. J. exp. Med. 121, 477.

Matile, P. (1964). Die Funktion proteolytischer Fermente bei der Proteinaufnahme durch Neurospora crassa. Naturwissenschaften 51, 489.

Matile, P., Balz, J. P., Semaden, E. \& Jost, M. (1965). Isolation of spherosomes with lysosome characteristics from seedlings. Z. Naturw. 20 b, 693.

Nachlas, M. M. \& Seligman, A. M. (1949). Evidence for the specificity of esterase and lipase by use of three chromogenic substrates. J. biol. Chem. 181, 343.

Nachlas, M. M., Crawford, D. T. \& Seligman, A. M. (1957). The histochemical demonstration of leucine aminopeptidase. J. Histochem. Cytochem. 5, 264.

NesvadBa, H. (1962). Aminosäure- $\beta$-naphthylamide zur Aktivitätsbestimmung proteolytischer Fermente. Mh. Chem. 93, 386.

PITT, D. (1968). Histochemical demonstration of certain hydrolytic enzymes within cytoplasmic particles of Botrytis cinerea Fr. J. gen. Microbiol. 52, 67.

PITT, D. \& CoomBes, C. (1968). The disruption of lysosome-like particles of Solanum tuberosum cells during infection by Phytophthora erythroseptica Pethybr. J. gen. Microbiol. 53, 197.

Semaden, E. G. (1967). Enzymatische Charakterisierung der Lysosomenäquivalente (Sphärosome) von Maiskeimlingen. Planta 72, 91.

Walek-CzernecKa, A. (1965). Histochemical demonstration of some hydrolytic enzymes in the spherosomes of plant cells. Acta Soc. Bot. Pol. 34, 573.

Weissman, G., Kaiser, H. \& Bernheimer, A. W. (1963). Studies on lysosomes. III. The effects of streptolysins $\mathrm{O}$ and $\mathrm{S}$ on the release of acid hydrolases from a granular faction of rabbit liver. J. exp. Med. 118, 205. 